\title{
Species Composition of Fungi Participate in the Formation of Mycobiota of Some Essential Oil Plants Included in the Flora of Azerbaijan
}

\author{
N.R. Namazov* \\ Institute of Microbiology of the NAS of Azerbaijan, Baku, Azerbaijan \\ *Corresponding author
}

\section{A B S T R A C T}

\begin{tabular}{|l|}
\hline Ke y w o r d s \\
Essential oil plants, \\
Mycobiota, Ecological- \\
trophic relations, \\
Biotrophy, Polytrophs
\end{tabular}

Keywords

Essential oil plants, trophic relations,

Biotrophy, Polytroph

\section{Introduction}

The fact that the Republic of Azerbaijan has extremely rich and colorful vegetation cover is one of the facts that have been confirmed. Thus, over 4700 plant species spread in this area, of which more than 1500 are medicinal (12). Therefore, the study of plant resources, analysys of their distribution laws, bioecological, phytocenology and ontogenetic properties, as well as the study of the microbiological, mycological, ecological and biotechnological bases of their use for practical purposes, is one of the most important issues and this is one of the priorities of a number of science fields, including microbiology.
It is known that in recent times bioecological balance in a global scale in the direction of disbalance undergoes fundamental changes. This is in turn creates real difficulties in the vital activities of the world of living beings including plant, animal and human organisms. In a disadvantaged environment needs of living things, including people to the products of natural origin is increasing, which have a healing-prophylactic effectes. According to these properties available plant products which this feature is realizes with their biological active ingredients that they have. Such substances an example can be cited alkaloids, essential oils, flavonoids, glycosides, coumarins, vaccines, resin, camellias, etc (1, 5, 16-18). Antifungal medicinal preparations within natural or 
synthetic origins obtained from aromatic or medicinal plants are distinguished by low toxicity and high activity. Therefore, searching antifungal substances within the wild flora is more appropriate and leads to prospective researches.

As mentioned, more than 1500 species of plants included in the flora of Azerbaijan has medical important(12). Essential oils is as a biologically active matters among of composition elements which by the chemical nature they are mixture of various substances coordinated with each other and their component content is consisting at oxidized terpenes, phenols, aldehydes, esters, acetates, lactones and ketones(4, 6, 11). Essential oil plants containing these compounds is considered as the natural source of interest for clinical and folk medicine(1).

On the other side, plants currently used in folk medicine constitute a small part of all essential oils plants and at the same time, they are characterizes as one of the settlements of microorganisms, including those of their phytopathogenic, toxic, allergen species(2-3). Investigating this issue is among the problems waiting to be solved today, at least for the reason that from the activity of the phytopathogenic microorganisms, including the fungus, the biological productivity of the plants weakens, also the number of individuals in their populations decreases(15). The prevention of this is one of the urgent problems of the modern era, which beginning point is to identify of species composition of living things which specific to plant or plant groups and cause to decline biological productivity of plants.

For this reason, the purpose of this work was dedicated to characterization of species composition of fungi participate in the formation of mycobiota of some essential oil plants included in the flora of Azerbaijan and pathologies committed by them.

\section{Materials and Methods}

As an object of research was selected essential oil plants, their mycobiota included in the cultural and wild flora of Azerbaijan. For this purpose, were taken samples from vegetative or generativ organs of more than 100 species of essential oil plants that assumes had fungi, which spread in 7 economic regions of Azerbaijan (Aran, Absheron, Daghlig Shirvan, Ganja-Gazakh, Lankaran, Guba-Khashmaz and ShakiZagatala). At the same time, were used methods of planned route and choosing standing areas for stationary observations which is widely used in the course of mycological research. Taken of sampling was carried out by seasons. Overall, more than 3,000 samples were taken during the research and analyzed according to the purpose of the study.

Development of taken samples was carried out mainly in the laboratory of Microbiology of the Institute of Microbiology of ANAS.

In the analysis of collected samples were used modern mycology and phytopathology methods(13-14) that approached to the purpose of work.

As a nutrient medium for the taking to the pure culture of fungi found on studied plants were used medium such as at malt juice agar (MJA), rice agar(RA), starch agar (SA) and potatoes agar (PA), Chapek and Chapek-Doks agar. Preparation, sterilization and pouring of mediums to the Petri dishes were carried out according to known methods. The samples which alleged has fungi was heldes to nutrition mediums and for certain period (up to 10 days) puts to the thermostat $\left(26^{\circ} \mathrm{C}\right)$ and kept until a colony is formed. After colony or mycelium is formed visualized and for the taking pure culture it moved to the new medium. The culture is monitored by means of a microscope. During the whole process, 
colony forming date, forms, color, color of the back side (revision), smell, form of mycelium, the formation of conids and other derivatives and their forms, dimensions, etc. changes registered. Results acquired in laboratory conditions, as well as the results of the field observation performed identification of fungi or pathologies caused by fungi. During identification of fungi were use determiner having cultural, morphological, and biological $\operatorname{sign}(7,10)$, as well as the base data of $\operatorname{IMA}(8)$.

\section{Results and Discussion}

From the result of analysis of samples taken from the essential oil plants included in the flora of Azerbaijan in 2013-2017 became clear that, in generally, in the formation of their mycobiota participates 161 species of true and like-fungi organizms. So that, 93,2\% of registered fungi species belong to real (Mycota), 6,8\% to like fungi organisms (Chromista).

It was determined that 14 species of real fungi (Absidia ramose(Zopf) Lendn., Actinomucor elegans (Eidam) C.R. Benj. \& Hesselt. , Mucor circinelloides Tiegh.,M. corticola Hagem, M.hiemalis Wehmer,M. mucedo (Tode) Spreng., M.odoratus Treschew, M.pentrincularis Naumov, M.plumbeus Bonord., M.ramosissimus Samouts, $M$. racemosus Fresen, Rhizopus nicricans Ehrenb., Rh.oligosporus Saito, Rh.stolonifer (Ehrenb.) Vuill.,) are includes in the department of Zygomycota, 109 species (Aspergillus awamori Nakaz, A. flavus Link, A.fumigatus Fresen, A.mollis Berk., A.niger Tiegh., A.ochraceus K. Wilh, A.repens(Corda) Sacc., A.ustus (Bainier) Thom \& Church, A.versicolor (Vuill.) Tirab., Penicillium chrysogenum Thom, P.citrinum Thom, P.cyclopium Westling, P.expansum Link., P.funiculosum Thom, P.janthinellum Biourge, P.lanozum Westling, P.notatum Westling, P.purpurogenum Stoll, P.rubrum Stoll,
P.simplicissimum(Oudem.)Thom, P.variabile Sopp, P.variotii (Bainier) Sacc., Botrytis cinerea Pers, Sclerotina graminearum Elenev ex Solkina., S.sclerotiorum (Lib.) de Barv, S. libertiana Fuskel, Sphaerotheca pannosa (Wallr.) Lév. Podosphaera xanthii (Castagne) U. Braun \& Shishkoff, Erysiphe cichoracearum DC., E.communis (Wallr.) Schltdl, E.umbelliferarum (Lév.) de Bary, E.trifolii Grev., Cercospora anethi Sacc., Cladosporium cladosporioides(Fresen.)G.A. de Vsries, C.herbarum (Pers.) Link, C.gossypii Jacz., C. transchelii Pidopl. \& Deniak, Sphaceloma menthae Jenkins, Monilia sitophila (Mont.) Sacc, Pseudopeziza medicaginis (Lib.) Sacc., Aureobasidium pullulans (de Bary) G. Arnaud, Septoria carotae Nagorny, S.flagellifera Ell. et Ev., S. glycines Hemmi, S.lactucae Pass, S.menthae (Thüm.) Oudem., S. salviae-pratensis Pass., S.sojae Syd. \& E.J. Butler, S.tanaceti Niessl, S.valerianae Sacc. \& Fautrey, Heterosporium syringae Oudem., Phyllosticta thymi Vasyag., Ph.trifolii Richon, Ph.vulgaris Desm. \& Roberge, Fuzarium dimerum Penz., $F$. gibbosum Appel \& Wollenw F.moniliforme J. Sheld., F.oxysporum Schecht, F.semitectum Berk. \& Ravenel, F.sporotrichiella Bilai., F.solani (Mart.) Sacc., Colletotrichum circinans (Berk) Vogl, C.higginsianum Sacc., C. kruegerianum Vassiljevsky, C. panacicola Nakata \& S. Takim., C.ocimi Damm, C.valerianae Kwash., Sordaria fimicola (Roberge ex Desm.) Ces. \& De Not, Nigrospora maydis (Garov.) Jechová, Trichoderma hamatum (Bonord.) Bainier, T.harzianum Rifai, T.koningii Oudemans, T.viride Pers., T.roseum (Pers.) Link, Thielaviopsis basicola(Berk. \& Broome) Ferraris, Verticillium albo-atrum Reinke \& Berthold., V.dahile Kleb., V.lateritium (Ehrenb.) Rabenh.,Alternaria alternata Keissler, A.chrysanthemi E.G. Simmons \& Crosier, A.radicina Meier, A.tenuissima (Nees) Wiltshire, A.solani (Ellis \& G. Martin) L.R. Jones, Pleospora herbarum (Pers.) 
Rabenh. ex Ces. \& De Not., Phoma achilleae (Sacc.) Traverso, Ph. anethi (Pers.) Sacc., Ph. betae Frank, Ph. capsici Magnani, Ph.destructiva Plowr, Ph.eupyrena Sacc., Ph.exigua Desm., Ph.lavandulae Gabotto Ph.medicaginis Malbr. \& Roum, Ph. pomorum Thom., Ph.dauci Arx. Macrosporium commune Rabenh., M.macrosporum (Eliasson) Sawada, Stemphylium botryosum Wallr, St.ilicis Tenqwall, St.macrosporoideum (Berk.) Sacc., Ascochyta anethicola Sacc., Asc.betae Prill et. Delacr. Asc. imperfecta Peck, Asc. iridis Oudem, Asc.leonuri Ellis \& Dearn., Asc.sojikota sojicola Nelen, Asc.foeniculina McAlpine, Asc.vulgaris Kabát \& Bubák, Phomopsis hyperici) Ascomycota, 27 (Gymnosporangium clavariaeformae (Wulfen) DC., G.cornutum Arthur ex F. Kern, Puccinia anethi Fuckel, P. anthemidis P. Syd. \& Syd., P.artemisiae Fuckel, P.iridis Wallr., P.matricariae Syd., P.menthae Pers., Puccinia nigrescens L.A. Kirchn, $P$. petroselini (DC.) Lindr, P.polygoni (Pers.) J. Schröt, P. porri ((Sowerby) G. Winter, Uromyces appendicutatus (Pers.) Link, U.erythronii (DC.) Pass., $U$. striatus J. Schröt., Aecidium foeniculi Castagne, Ustilago zeae (Beckm.) Unger. Pleurotus ostreatus (Jacq.) P. Kumm. Typhula trifolii Rostr. Ganoderma applanatum (Pers.) Pat. , Inonotus hispidus (Bull.) P. Karst., Fomes fomentarius (L.) $\mathrm{Fr}$, Fomitopsis pinicola (Sw.) P. Karst. Heteroporus biennis (Bull.) Lázaro Ibiza, Schizophyllum commune Fr., Phellinus igniarus (L.) Quél., Stereum hirsutum (Willd.) Pers.) to the department of Bazidiomycota. Was determine that 11 species of fungi-like organisms(Albugo candida (Pers. ex J.F. Gmel.) Kuntze, Phytophtora capsici Leonian, Ph. infestans (Mont.) De Bary, Ph. citrophthora (R.E. Sm. \& E.H. Sm.) Leonian. , Ph. phaseoli Thaxter, $P h$. melangenae K.Sawade, Ph. parazitica Dastur, P.destructor Casp, P. cubensis Berk. \& M.A. Curtis, P. parasitica (Pers.) Tul. and
Plasmopara dauci Savul. \& O. Savul) belongs to the departament of Oomycota.

It should be noted that mycological research in the territory of Azerbaijan is studing for a long time and the in the research undertaken so far was recorded thousands of fungi species. Comparing the fungi registered in the course of these studies to those which known to be spread in Azerbaijan, became clear that, the majority of recorded fungi, more precisely, 95,7\% have been identified in Azerbaijan condition, that is most of them participating in the formation of mycobiot of Azerbaijan and this species is known by science. Despite this, among the recorded fungi is encountered species which spread in Azerbaijan were registeret in first time during research. The number of species suitable for this characteristic is equal to 7 (Fusarium dimerum Penz., Exserohilum longirostratum (Subram.) Sivan., Mucor ramosissimus Samouts, Nigrospora maydis (Garov.) Jechová, Penicillium simplicissimum (Oudem.) Thom, Phoma medicaginis Malbr. \& Roum. and Sclerotinia graminearum Elenev ex Solkina).

Fungi, such as heterotrophic organisms participates in the formation of pathogenic or epiphythmic mycobiota of plants(15) and thereby exerts its effect on plants. The fungi that are involved in the formation of epiphitic mycobiota mainly are nourished by their exudates of plants and do not cause considerable changes in their biological activity.

But, species involved in the formation of pathogenic mycobiota is causes contrariwise, such as during using content components of plants causes at the change of their biological activity and in most cases its weakens. From the point of view to kept up their in the constant of attention, to identification of their species composition, development cycles, and 
so on. is a necessary information for the preparation of preventive measures against them. From this research became clear that, in the formation of mycobiota of this studied essential oil plants also also actively participate pathogen species and at least $2 / 3$ of the registered fungi are involved in the appearance of various pathologies in this or that extent.

It should be noted that, fungi that are involved in the creating of these or other pathologies are characterized as true biotrophs or polytrophs. Those are characterized as true biotrophs contains fungi as Aecidium foeniculi Castagne, Gymnosporangium clavariaeformae (Wulfen) DC., Phytophtora capsici Leonian, Ph. citrophthora (R.E. Sm. \& E.H. Sm.) Leonian., Plasmopara dauci Savul. Tr. Et., Puccinia artemisiae Fuckel, P.matricariae Syd., P.menthae Pers., Uromyces striatus J. Schröt., Ustilago zeae(Beckm.) Unger and oth. and they are cause diseases on plants such as brown decay, white decay, rust,antimony, flour dew, fitophtoroz, perinospora, plazmopar. As for the polytrophic they differ in both the number and the variety of pathologies cause by them. So that, about $75 \%$ of fungi which has the ability to commit to this or other pathology fall into the share of polytrophs. To the illnesses they are cause includes fusariosis, spotted, fade, septoria, different color decay, mold, alternarioz and so on. Among of disease-makers, fungi such as Ascochyta anethicola Sacc., Asc.foeniculina McAlpine, Alternaria alternata Keissler., A.tenuissima (Nees) Wiltshire, F. gibbosum Appel \& Wollenw., F.moniliforme J. Sheld., F.oxysporum Schecht, F.solani (Mart.) Sacc., Phoma lavandulae Gabotto Phomopsis achilleae (Sacc.) Traverso, Ph.dauci Arx., Phyllosticta trifolii Richon, Septoria menthae (Thüm.) Oudem., S. salviae-pratensis Pass., Trichothecium roseum (Pers.) Link, Verticillium albo-atrum Reinke \& Berthold.,
V.dahile Kleb and oth. are considered most widespread fungi on the essential oil plants.

Interestingly, among of fungi recorded in reseach and caused different pathologies toxigenic fungi is also takes enough part(2) and mycotoxins synthesized by them is considered serious sources of danger for human health(9). Therefore, preparation of security mycological principles during use of essential oils is one of the issues waiting its solve which confirms from obtained results .

Thus, from the carried out of research became clear that, although essential oil plants contain fungicidal compounds they ere characterized as one of the places where fungi are settles and feedings. In general, in the formation of their mycobiota are takes part 161 species of fungi and like-fungi organizms. The vast majority of registered fungi belong to biotrophs and polytophs in terms of ecotrophic relationships, which also cause various pathologies in plants. Among these more frequently recordes diseases such as stain, rust, fusariosis, floury dew, fading, anthracnose and so on.

\section{References}

1. Babar Ali, Naser Ali Al-Wabel, Saiba Shams, Aftab Ahamad, Shah Alam Khan, Firoz Anwar. Essential oils used in aromatherapy: A systemic review // Asian Pacific Journal of Tropical Biomedicine., 2015, v. 5, Issue 8, p. 601-611

2. Bakshaliyeva K.F. Characteristics by quantity and species composition of toxic fungi spread on different biotopes of Azerbaijan.// Azerbaijan Agrarian Sciences, 2016, № 5, p. 92-95.

3. Bakshaliyeva K.F. Perspectives of use of medicinal plants included in the flora of Azerbaijan as a producer of antimicrobial pharmacological active substances 
(review).// Scientific works of the Institute of Microbiology of ANAS, 2016, v.14, №1, p. 317-324.

4. Bubenchikova V.N., Starchak Y.A. Investigation of thyme essential oil twofaced. // Pharmacy, 2015, № 6, p. 7-9

5. Essential oils of spicy-flavoring plants // Successes of modern natural science, 2013, № 9, p 135-139;

6. Gedko N.V., Shutova A. G., Pobolovets T. A., Titok V.V. The chemical composition of volatile essential oils released into the atmosphere by leaves of representatives of the family Lauraceae Juss. in greenhouse culture, and their antimicrobial activity. / Reports of the National Academy of Sciences of Belarus, 2016, v. 60, № 6, p. 91-97

7. http://www.indexfungorum.org

8. http://www.mycobank.org/MycoTaxo.asp $\mathrm{X}$

9. http://www.e-osnova.ru/PDF/osnova_ 1_0_3.pdf

10. Kirk P. M., Stalpers J.A. Dictionary of the fungi, 10th edn. CABI publishing / P. M. Kirk, P. F. Cannon, D. W. Minter.Wallingford(UK), 2008, $600 \mathrm{p}$.

11. Kumar S., Pandey A.K. Chemistry and biological activities of flavonoids: an overview.// Sci. World J., 2013, vol. 13, p. 1-16.
12. Mehdiyeva N.P. Biodiversity of medical flora of Azerbaijan. Baku: "Letterpress", 2011, p 186.

13. Methods of experimental mycology. Edited by. Bilai V.I. Kiev: Naukova Dumka. 1982, 500p.

14. Netrusov A.İ, Egorova M.A., Zakharchuk L.M. and oth. Practicalwork on microbiology. M.: Publishing Center "Academy", 2005, p 608.

15. Perevedentseva L.G. Mycology: fungi and fungi-like organisms.СПб.: Publishing house "Lan", 2012, p 272.

16. Saad N.Y., Muller C.D., Lobstein A. Major bioactivities and mechanism of action of essential oils and their components // Flavour and Fragrance J., 2013, vol. 28, № 5, p. 269-279.

17. Stoilova I. S., Wanner J., Jirovetz L., Trifonova D., Krastev L., Stoyanova A. S., Krastanov A. I. Chemical composition and antioxidant properties of juniper berry (Juniperus communis L.) essential oil // Bulgarian Journal of Agricultural Science., 2014, vol. 20, № 2, p.227-237.

18. Yarosh A.M., Tonkovtseva V.V., Boroda T.V., Serobaba L.A., Seredina O.S. et al. Essential oil composition of Lavandula officinalis and Juniperus virginiana and its effect on human nervous system //Works of the State Nitit. Botan. Gard., 2015, v.141, p.79-85

\section{How to cite this article:}

Namazov, N.R. 2018. Species Composition of Fungi Participate in the Formation of Mycobiota of Some Essential Oil Plants Included in the Flora of Azerbaijan. Int.J.Curr.Microbiol.App.Sci. 7(11): 1867-1872. doi: https://doi.org/10.20546/ijcmas.2018.711.211 